\title{
PRELIMINARY REPORT ON K/AR DATING IN THE SOUTH-EASTERN PART OF THE IVIGTUT REGION
}

\author{
Ole Larsen
}

Qôrnoq fjord samples

In the Ivigtut region the Ketilidian supracrustal rocks are exposed mainly on Arsuk $\varnothing$ and in a narrow belt stretching along the margin of the Inland Ice (Berthelsen \& NoeNygaard, 1965; Windley et al., 1966). This belt narrows to less than $1 \mathrm{~km}$ along the north side of Qôrnoq fjord. The metamorphic grade of the supracrustal rocks increases southwards from lower greenschist facies in northern Grænseland and on Midternæs to epidote amphibolite facies around Qôrnoq fjord and Kînâlik.

Along Qôrnoq fjord the pelitic sediments of the Vallen Group are represented by a sequence of fairly coarse-grained phyllites. These rocks are all rich in muscovite and most samples also contain some biotite. If these rocks were not affected by post-Ketilidian plutonism, they would be ideal for K/Ar dating of the Ketilidian metamorphism. K/Ar age determinations on pre-Ketilidian gneisses in the Ivigtut region reported previously have all given ages around $1600 \mathrm{~m}$.y. reflecting the end of the late-Ketilidian plutonism. The present $\mathrm{K} / \mathrm{Ar}$ ages demonstrate that the Ketilidian metamorphism is at least $1800 \mathrm{~m}$.y. old. This observation is in agreement with the result of $\mathrm{K} / \mathrm{Ar}$ dating in the southern Frederikshåb region where preKetilidian gneisses give ages ranging to as young as 1800 m.y. (Larsen \& Møller, 1968).

\section{Kînâlik samples}

Three different rocks have been dated from the Kînâlik area (table 3). 74109 is a biotite schist of presumed metavolcanic origin, 74116 represents augen gneiss which is believed to have formed by synkinematic granitisation of the metavolcanics and finally 74115 is a pegmatite cutting the Ketilidian schists.

The K/Ar ages demonstrate that Kînâlik is an area of late thermal overprinting probably related to the Gardar plutonic episode. The dates on the Qôrnoq fjord samples demonstrate that Kînâlik must have been marginally located in relation to the Gardar activity, so the dated minerals might well have suffered only partial argon loss at about 1150-1200 m.y., which is the K/Ar age commonly measured on Gardar rocks in the Ivigtut region. 


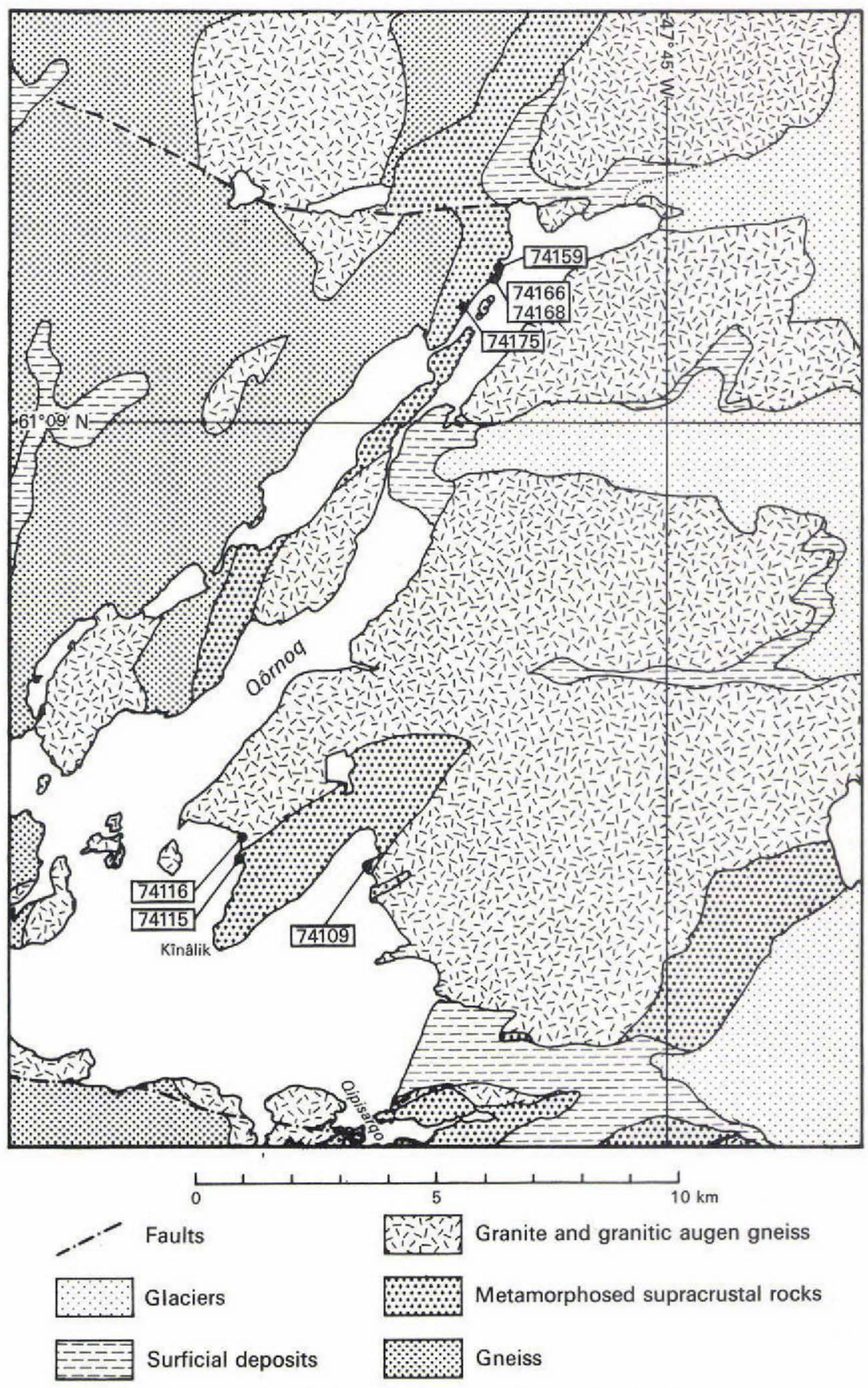

Fig. 7. Geological sketch map (modified after GGU 1:100 000 sheet $61 \mathrm{~V} .1 \mathrm{~S}$, Ivigtut) of the south-eastern part of the Ivigtut region showing the localities of the dated samples. 
Table 3. Potassium - argon dates from the south-eastern part of the Ivigtut region.

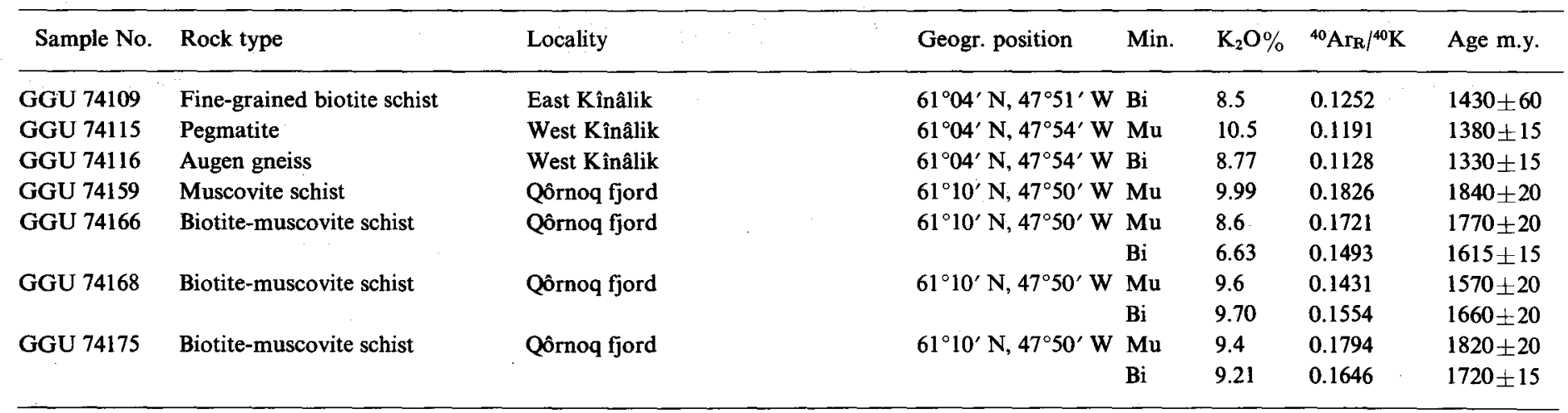

Decay constants: $\lambda_{\mathrm{e}}=5.85 \times 10^{-11} \mathrm{ye}^{1} ; \lambda_{\beta}=4.72 \times 10^{-10} \mathrm{y}^{-1} ;{ }^{40} \mathrm{~K} / \mathrm{K}=1.19 \times 10^{-4}$ 


\section{References}

Berthelsen, A. \& Noe-Nygaard, A. 1965: The Precambrian of Greenland. In Rankama, K. (editor) The Precambrian, 2, 113-262. New York \& London: Interscience.

Larsen, O. \& Møller, J. 1968: K/Ar age determinations from western Greenland 1. Reconnaissance programme. Rapp. Gronlands geol. Unders. 15, 82-86.

Windley, B. F., Henriksen, N., Higgins, A. K., Bondesen, E. and Jensen, S. B. 1966: Some border relations between supracrustal and infracrustal rocks in South-West Greenland. Rapp. Gronlands geol. Unders. 9, 43 pp.

\section{ROUTINE K/AR AGE DETERMINATIONS ON ROCKS FROM GREENLAND CARRIED OUT FOR GGU IN 1970}

\section{Bridgwater}

The programme of commercial age determinations started in 1969 (Bridgwater, 1970) was continued to supplement the work carried out by the University of Copenhagen (Larsen, this report). The material dated represents a rather heterogeneous collection of rocks from many parts of Greenland about which information was required for current geological work but which were not included in existing age determination projects. All the results obtained are listed whether or not the "ages". have a clear geological significance, since a major reason for carrying out this form of reconnaissance survey is to test the suitability of $\mathrm{K} / \mathrm{Ar}$ methods for making more detailed studies. Full analytical data is available on request from GGU. Unless otherwise stated the results given are means of three determinations. The constants used are:

$$
\begin{aligned}
& \lambda_{\mathrm{e}}=0.584 \times 10^{-10} \mathrm{yr}^{-1} \\
& \lambda_{\beta}=4.72 \times 10^{-10} \mathrm{yr}^{-1}
\end{aligned}
$$

The references given are those to the most relevant publications. In the case of rocks of which there are no published accounts, the name given is that of the collector.

\section{North Greenland}

The geological background for the samples listed here is to be found in Dawes \& Soper (1970 and this report) and Dawes (1971). The geographical coordinates used are from the U.S.A.F. World Aeronautical Chart 1:1000 000, 5th edition. 